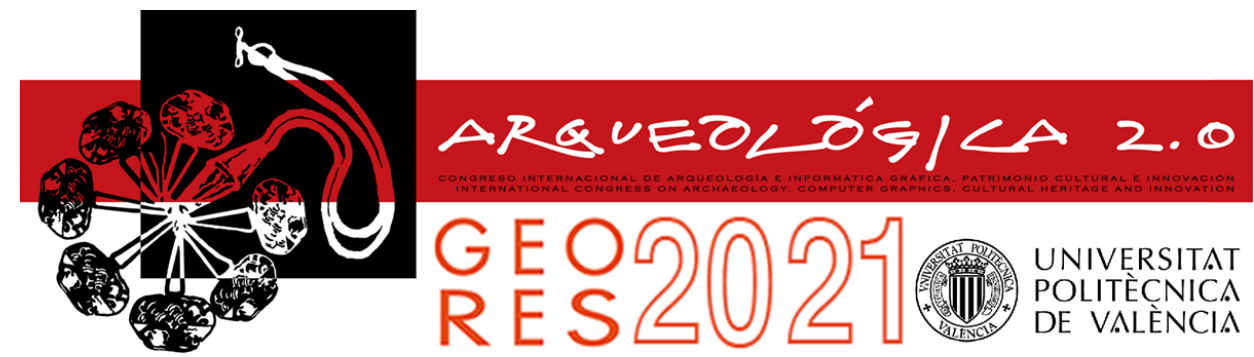

Proceedings of the joint international event $9^{\text {th }}$ ARQUEOLÓGICA 2.0 \& $3^{r d}$ GEORES Valencia (Spain). 26-28 April 2021

\title{
HOW WERE THE TAPESTRIES IN THE SALA DI SATURNO OF PITTI PALACE ARRANGED? GEOMATICS AND VIRTUAL REALITY FOR ART CURATORS
}

\author{
Grazia Tucci”, Valentina Bonora, Alessandro Conti, Lidia Fiorini
}

GeCO Lab, Dipartimento di Ingegneria Civile e Ambientale, Università degli Studi di Firenze, Via di Santa Marta 3, 50139 Florence, Italy.grazia.tucci@unifi.it; valentina.bonora@unifi.it; alessandro.conti@unifi.it; lidia.fiorini@unifi.it

\begin{abstract}
:
Three-dimensional acquisition techniques, reality-based modelling and virtual reality are tools used in Digital Humanities prevalently for displaying the results of a study, but they can also suggest new methods of investigation to humanities scholars. In a case study regarding art history, these techniques made it possible to recreate the layout of the Sala di Saturno in Pitti Palace (Florence) in the $17^{\text {th }}$ century, based on information obtained from archive documents on the tapestries designed for that hall and a 3D model expressly elaborated with geomatic techniques. The results were summarised in a video showed in 2019 during the exhibition on tapestries dedicated to Cosimo I de' Medici. A tool was also developed to assist exhibition and museum curators in their work. Through virtual reality, they can design temporary exhibitions or modify the display of the works of art in a museum in a realistic way, using visually and metrically accurate models of the pieces and exhibition rooms.
\end{abstract}

Keywords: 3D modelling, virtual reality, digital humanities, curatorship, tapestries, sala di Saturno

\section{Introduction}

The research methodologies that involve computing technologies to perform or support traditional humanities methods are now widely diffused.

The expression Digital Humanities was born mainly in relation to text-based disciplines. In such a context, disciplines in which imprecision, qualitative information and individual interpretations are traditionally the norm, had to deal with precision, quantitative measurement, and accuracy.

The Spatial (Gregory \& Murrieta-Flores, 2016) and Visual Digital Humanities (Münster \& Terras, 2019). have been even more successful and have renewed methods for comparing data, integrating sources, and presenting research results in many disciplines.

Among the different ways of using visual resources, the use of 3D models for reconstructions and simulations has strongly emerged with the diffusion of digital technologies among the wider public, perhaps not expert in Cultural Heritage $(\mathrm{CH})$ but already aware of the digital graphics language, assimilated by movies or videogames (Münster, Friedrichs, \& Hegel, 2018; Mandelli et al., 2019; Fazio \& Lo Brutto, 2020).

The consequence is that the $3 \mathrm{D}$ tools and the various declinations of eXtended Reality (XR), like Augmented Reality (AR), Mixed Reality (MR) and Virtual Reality
(VR), were initially conceived by humanistic scholars, in particular museum and exhibition curators, for communication to the public, especially to the younger generations or to people considered less interested in traditional exhibitions (Gifreu-Castells, 2019; Huaman, Aceituno \& Sharhorodska, 2019; Eliseu, Lopes, Ribeiro. \& Oliveira, 2020)

The possibility of virtually accessing places of culture is particularly highlighted during the current COVID-19 pandemic when many museums are using virtual tools to maintain and consolidate their dialogue with the public. (Greco \& Della Torre, 2020; NEMECH, 2020; NEMO, 2020).

Actually, the digital revolution has so radically transformed our cognitive approach (Greco, 2019) that the starting point for new research often stems from the feasibility of digitally investigating and representing their results (Tucci, Bonora, Conti \& Fiorini, 2017).

It is not merely about adapting to a trend, digitisation is reconfiguring the role of those who produce and manage art (such as museums) and new, consolidated business models are also emerged (Lazzeretti \& Sartori, 2016).

The aim of this article is to show the benefits of geomatic surveying techniques and $3 \mathrm{D}$ modelling in the field of Digital Humanities, in particular:

- By fostering new investigations in art history; 
- by developing new tools for the curatorship of art exhibitions;

- By improving the comprehensive management of museums.

Experiences concerning the Sala di Saturno of Pitti Palace (Florence) are presented. After a brief historical overview (part 2), a case study concerning the tapestries designed for this hall in the $17^{\text {th }}$ century is illustrated (part 3). The methods of acquisition and the investigations that led to the reconstruction of the original arrangement of the tapestries are then explained (part 4). An application for the design and management of museum exhibitions in VR is also outlined (part 5).

\section{Historic background}

Pitti Palace is the largest palace in Florence (Fig. 1) and was one of the great Italian royal palaces, inhabited by the dynasties of the Grand Dukes of Tuscany (Medici and Hapsburg-Lorraine) and, after the unification of Italy, by the Savoia royal family for five years (Bertelli, 2002). It currently houses four museums that are part of the Uffizi Galleries complex.

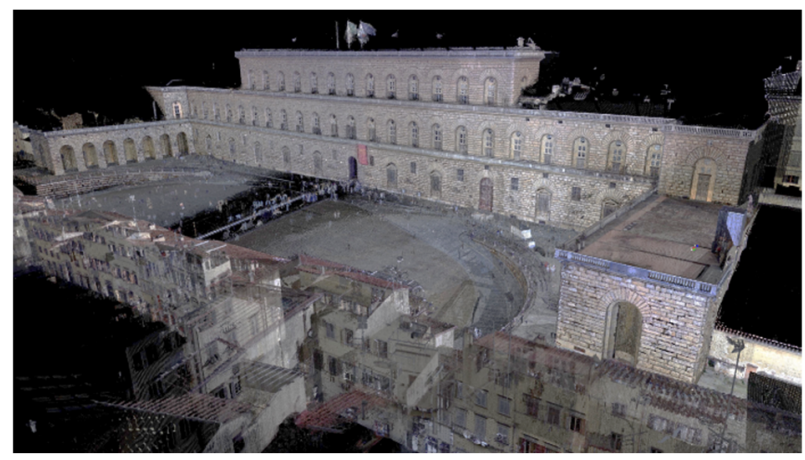

Figure 1: General view of the main façade of Pitti Palace (point cloud obtained by laser scanner survey).

The original core takes its name from the Pitti family who built it in the middle of the $14^{\text {th }}$ century. In 1550 it was bought by Eleonora di Toledo, wife of Cosimo de' Medici, who in 1569 became the first Grand Duke of Tuscany.

The palace was enlarged several times, in the $17^{\text {th }}$ century the façade was increased by adding eight windows on each side. The expansion on the left side of the piano nobile consists of a suite of staterooms connected with the Grand Duke's apartment. These rooms, in which guests were progressively admitted according to their rank, are called the Planetary Rooms because they are entitled to the gods associated with the Ptolemaic planets, in homage to Galileo, who had just dedicated the discovery of Jupiter's satellites to Grand Duke Cosimo II (Bandini, Felici; Lanfranchi \& Mariotti, 2009).

The decoration of the rooms was based on complex allegories linking the deities of classical mythology, the cardinal virtues, and the astrological influences of the planets on the phases of the sovereign's life. The Sala di Saturno (dedicated to the attainment of the wisdom that leads to eternal fame) was the last of the sequel. It was already a part of the Grand Duke's private apartment and secret hearings were held there.
The ceiling had a very rich decoration in stuccoes and paintings designed by the Italian Baroque master Pietro Berrettini (also known as Pietro da Cortona) and executed in 1665 by his pupil Ciro Ferri. Instead, the walls were originally unadorned, as the main floor was used as a winter residence and therefore were intended to be covered with tapestries which, in addition to being a decorative element, also performed a thermoinsulating effect.

Ferdinando II wanted some of the tapestries dedicated to the works of his ancestor Cosimo I to be placed in the Sala di Saturno, the Golden Age deity. The tapestries, designed by famous painters and woven in the Florentine Tapestry Manufactory directed by Pietro Févère, thus celebrated the Grand Duchy as new golden age (Griffo \& Meoni, 2019).

\section{The tapestries of the Sala di Saturno}

In 2019, the exhibition "Weaving a Biography. The tapestries in honour of Cosimo I" was held at Pitti Palace. In the exhibition, curated by the art historians Alessandra Griffo and Lucia Meoni, once again displayed the tapestries as a tribute to the first Grand Duke on the fifth centenary of his birth. Tapestries are particularly vulnerable works of art that can only be exhibited for short periods.

La Sala di Saturno is currently part of the Palatine Galleries and it would not have been possible to remove the paintings that are housed there for a temporary exhibition, which was therefore set up in the Sala Bianca. This is a very large room, and the tapestries could be comfortably admired by a large audience, but visitors lost the feeling of the context for which they were designed, so much so that the majestic tapestries appeared even larger than the Sala di Saturno (Fig. 2).

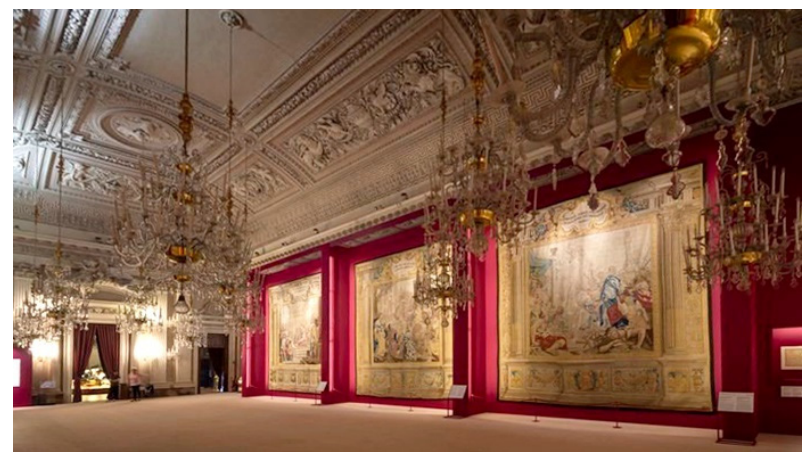

Figure 2: The tapestries dedicated to Cosimo I exhibited in the Sala Bianca of Pitti Palace.

An inventory of Pitti Palace dating back to 1688-96 reports that in the Sala di Saturno there were six tapestries of the series dedicated to Cosimo I, indicating their measurements but not the subjects and their disposition on the walls. The curators wanted to recreate the original appearance of the room starting from the dimensions of the tapestries, never compared so far with the actual size of the hall.

It is remarkable that this research, although also possible in the past with traditional manual measurements and drawings, has been conceived only now, when the use of spatial digitization, 3D models and digital reconstructions has become so widespread to be 
considered even by scholars who are not experts in these techniques.

The curators, therefore, required not to have a mere visual suggestion of the tapestries in the room, but to make accurate 3D models in real size of the room and the tapestries. So, they would empirically try to rearrange the tapestries in the room to study the most likely original disposition. It was also necessary that the model had a high visual quality for the communication project aimed at the visitors of the exhibition.

With respect to $3 \mathrm{D}$ digitizing techniques, in the Sala $d i$ Saturno there are currently many challenging objects and materials, among others gilding, frescoes and oil paintings, upholstery, marbles, furniture and many lamps and light sources. Considering that the study concerned only one room, it was initially planned to survey it both with laser scanning and photogrammetry and to select the best data acquired with the two techniques (Angheluță \& Rădvan, 2020).

\section{3D acquisitions}

The laser scanner survey was performed with a $Z+F$ 5010C scanner, also acquiring RGB values. Considering the complex geometry of the room and especially the vault, which has highly three-dimensional decorations, six scans were done in the hall (one in the centre, four in the corners and one in the splay of the window) and another two in the adjacent halls to show the relationship with the surrounding rooms (Fig. 3). For the best visual quality, scans were carried out under different conditions of natural and artificial lighting.

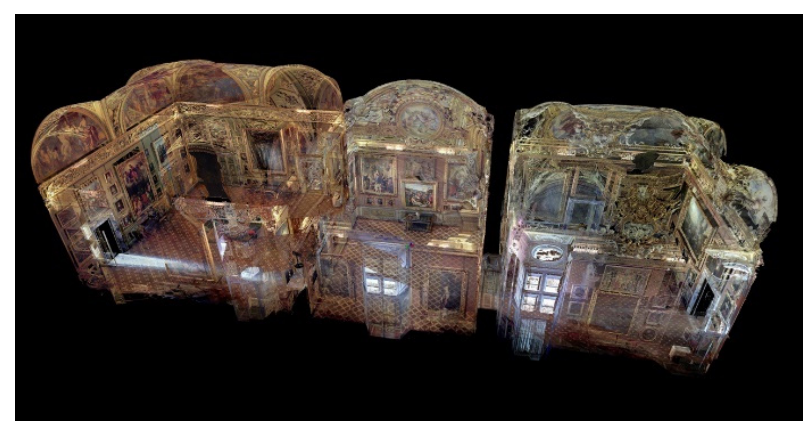

Figure 3: Laser scanner survey of the Sala di Saturno ( $\mathrm{n}$ the middle), between the Sala di Giove (on the right) and the Sala dell'lliade (on the left).

The images for the photogrammetric project were done with a Nikon D700 camera and Nikkor $50 \mathrm{~mm}$ f1.4 lens. To have the evenest illumination possible, all photos were taken with the windows closed and the museum lighting switched off, using instead a lighting balloon (Airstar, 2021) placed in the centre of the room which gives an intense and even illumination. Both orthogonal and convergent photos were taken towards the walls and the vault and around the corners between the surfaces, for a total of 842 images (Fig.4).

It was not possible to take tiered images, but as the room and its decorations were designed to be seen at eye level, it has been considered that some small gaps above the cornice or behind the sculptures on the vault were not significant for the aim of this project. It resulted that the photogrammetric model had a high geometric and visual quality, so the scans were used exclusively to determine the coordinates of the points used for scaling (Luhmann et al., 2019).

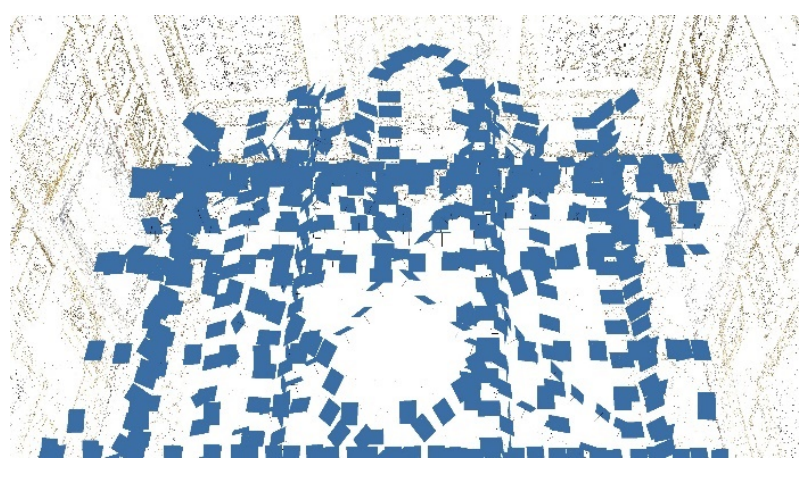

Figure 4: A visualization of the tie points of the photogrammetric model, also showing the estimated camera positions.

\section{The ancient layout of the hall}

Starting from the 3D model of the current state, a reconstruction of the Sala di Saturno in the $17^{\text {th }}$ century was carried out, removing all the paintings and furnishings present today (Fig. 5). Real-size models of the tapestries have also been created by applying highresolution images as textures.

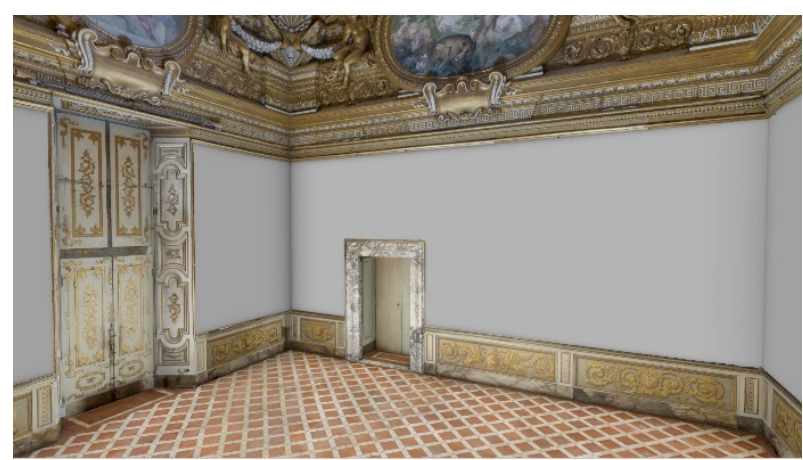

Figure 5: Reconstruction of the layout of the Sala di Saturno before its conversion into a picture gallery, used to study the disposition of the tapestries in the $17^{\text {th }}$ century.

Together with the curators, the arrangement of the tapestries listed in the inventory was then discussed. Each of the tapestries in the series has a central figure inserted into a frame, as if they were paintings set in an architectural order, with a socle, a column and a pilaster on both sides and an entablature at the top.

The approximately constant height of the tapestries corresponds to the distance between the floor and the moulding at the base of the vault, where it has been found a series of hooks from which the tapestries were presumably hung. In this way, the socle depicted in the tapestries corresponds to the simpler wainscoting at the base of the walls. The lengths of the tapestries, however, are considerably different, but there was no correspondence between the measure of the tapestries and the empty spaces of the walls. Rather, the total length of the tapestries was greater than the perimeter of the room, therefore it was not possible that they could simply be placed next to each other.

The curators were aware, however, that the tapestries could be partially overlapped, as they also had the function of protecting against the cold. Therefore, 
several attempts were made, considering that the bands with columns and pilasters on the sides of the tapestries could be paired to represent simple or coupled columns.

Given the constraints of the doors and windows and assuming that the tapestries were placed according to the chronological order of the Cosimo's life, the only possible layout is that the door to the Grand Duke's bedroom (currently hidden by a modern tapestry) should be opened and, on the other hand, the door that now leads to the next room (the Sala dell'lliade, not yet completed in those years) had to be covered by the tapestries (Fig. 6).

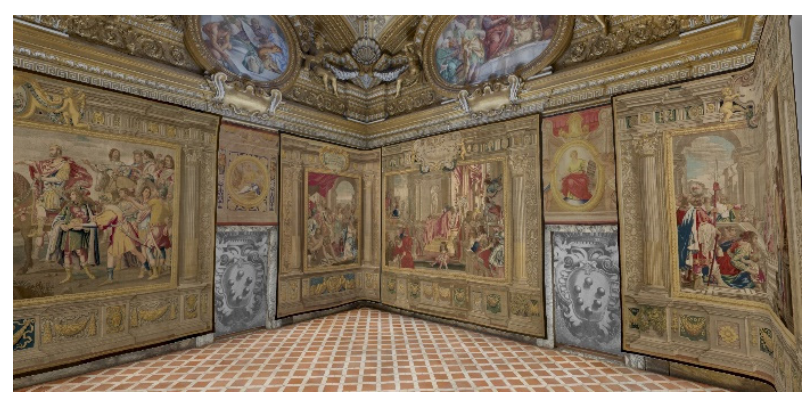

Figure 6: Reconstruction of the arrangement of the tapestries in the Sala di Saturno. The door on the left side is now covered by modern tapestry.

Some tapestries should also be folded at some corners. A possible confirmation of this reconstruction is that in some cases the figures are divided into two groups. If the tapestries were folded, the figures seemed to be face to face, and the perspective of the scene is accentuated. Other, smaller tapestries were placed above doors and as a door covering (Fig. 7).

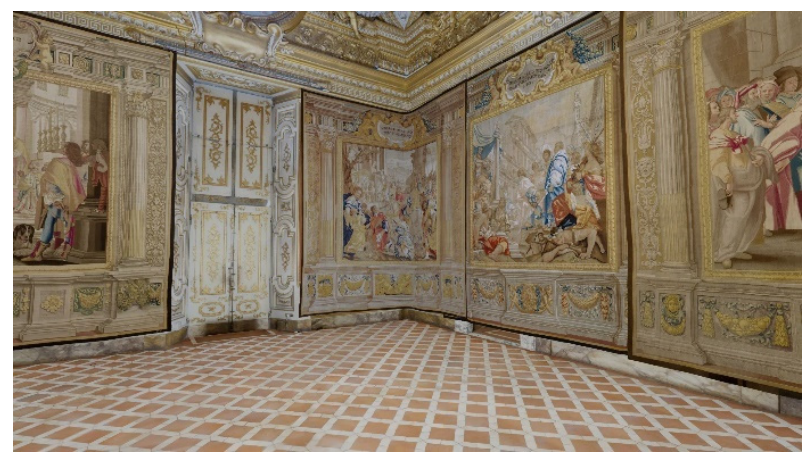

Figure 7: An example of the tapestries overlapped and folded in the corners. On the right wall, the door that now leads to the next room is covered, because the Sala dell'lliade was completed some years later.

\section{A video for communication}

On the communication side, the results of the study have been presented to the public by the Uffizi Galleries and GeCO Lab in a short video (LaboratorioGeCO, 2020). To summarize the function and position of the Rooms of the Planets in the palace, some already acquired pointclouds of the square were reused, in the spirit of the 'Open Data Directive' (2019) for the re-use of digital data. The video then illustrates the visitors' path to the Sala di Saturno, showing at first the photogrammetric model of the current layout, then a reconstruction of the architecture without the paintings. Afterwards, it is explained how the doors were modified and, finally, the supposed arrangement of the tapestries is shown.

\section{Virtual reality for curators}

The digital models of the room and the tapestries enabled the curators to carry out their research, but they always needed the assistance of a 3D expert and modifications could not be made and displayed in realtime.

Previous research has already shown how the management of museums can benefit from visually structured databases (Tucci et al., 2019a; Tucci et al., 2019b). BIM models (or H-BIM, in the case of museums in historic buildings) including data and 3D representation of works of art help museum managers in decision making by correlating information about the collections and the spaces in which they are located.

In this case, it was preferred to exploit virtual reality and allowing curators to personally manipulate and arrange the works of art within a realistic and metrically correct representation of the exhibition space. The creation of virtual environments essentially uses graphic engines born for developing videogames and therefore exploits the efforts made in this field for sufficiently intuitive interaction with the environment and the different assets. (Bekele, Pierdicca, Frontoni, Malinverni \& Gain, 2018) So even though virtual reality is not yet a widespread technology, even beginners can easily learn its use once the virtual environment has been correctly designed and built.

In this case, the virtual environment was built with the Unity graphic engine (Unity Technologies, 2021) starting from the 3D model in 3DS file format and not from a BIM model, which would have not been very meaningful regarding the mere geometry of a single room only. Both BIM and other 3D models must be converted in FBX file format before being imported into Unity, therefore many procedures are valid in both cases, even if with differences and limitations (Banfi, 2020).

By imagining the use of a curator, 3D models of the paintings currently on display in the Sala di Saturno were also created. For smooth interaction, all 3D models with a high number of polygons (high poly) were converted applying retopology and texture baking techniques into models with a low number of polygons (low poly) but maintaining a high visual quality (Fig. 8).

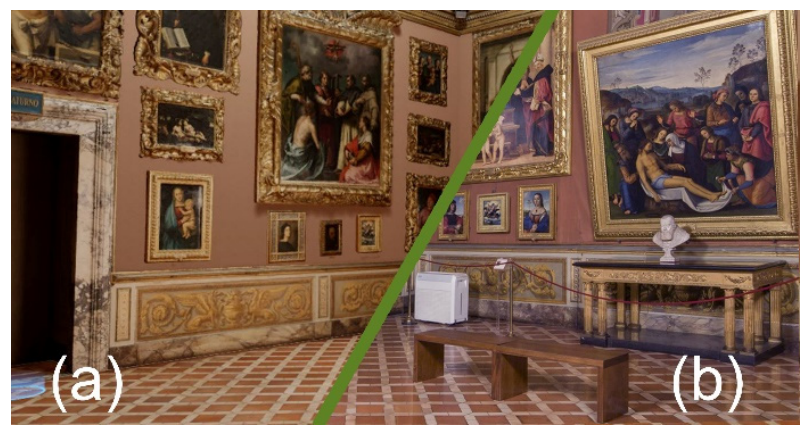

Figure 8: A comparison between the actual Sala di Saturno (a) and the VR model (b). 
The metadata of the works of art from the inventory records has been re-associated to the $3 \mathrm{D}$ models, so that they can also be browsed in the gaming engine.

The immersive virtual environment allows the user to visualize the life-size art assets by selecting (with several search keys) from a catalogue and placing them on the walls of the exhibition room. Therefore, the curator can study different layouts in real-time and record the various results (Fig. 9). There is also a "time machine" function for displaying how the layout of the works of art is changed over time.

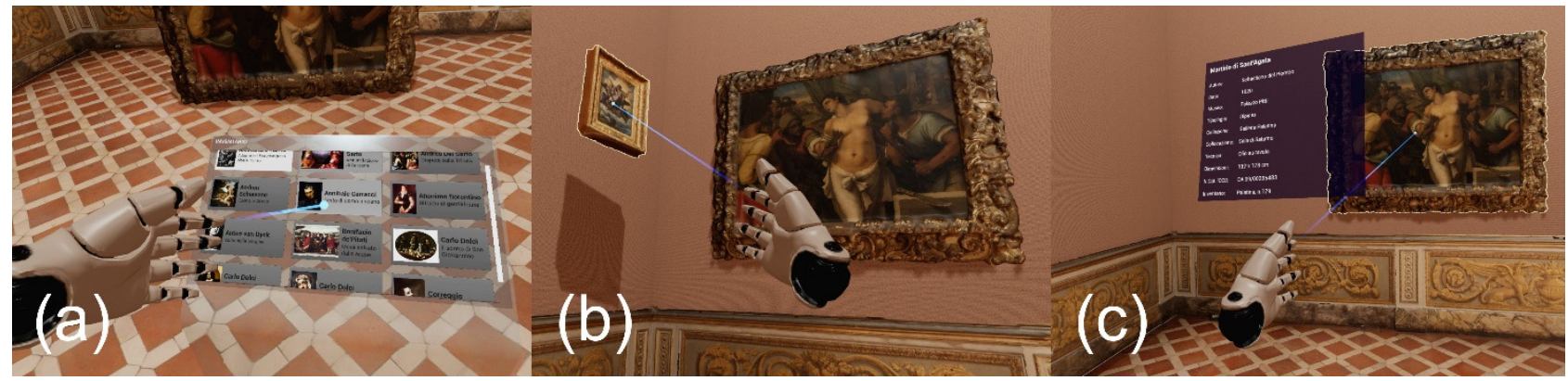

Figure 9: Some examples of the use of the virtual reality solution for museums and exhibitions. Selection of a work from a catalogue (a), arrangement of a painting on a wall (b), consultation of inventory data (c).

This can be used in different scenarios:

- For designing a display or a temporary exhibition, even without being in person at the exhibition site;

- For the pre-visualization of the spatial relationships of the works of art in a real space;

- For designing site-specific works of art;

- $\quad$ for archiving the sequence of the displays in a museum (in Italy this is requested by D.M. 113 2018);

- For creating virtual exhibitions in a realistic setting, according to thematic criteria or customised routes for visitors.

\section{Conclusions}

In the cultural heritage field, geomatic techniques for the acquisition of spatial data, 3D modelling and XR are not only tools used for recording and cataloguing or for visualisation, but also offer to Digital Humanities scholars a range of professional applications. The experience presented, concerning a room in Pitti Palace, has shown:

- The advantages provided by the use of 3D models in the study of the layout of the tapestries in the Sala di Saturno of Pitti Palace in the $17^{\text {th }}$ century;

- How 3D models and VR can be used by museum curators and managers for their professional activities;

- How the same models can be re-used for possible more traditional applications, like for communication projects and virtual exhibitions.

Extended reality technology could be applied to the virtual reconstruction of the ancient layout of the Sala di
Saturno to enable an even more immersive experience than with a video. The existing model can be easily adapted to see the reconstruction beyond the duration of the exhibition, either by allowing visitors to view it in augmented reality on-site or remotely using virtual reality devices.

The experience of art management would obviously be much more interesting if extended to the whole building and including non-visible works of art in the storage rooms also.

These applications are enabled using 3D models produced using geomatic techniques and therefore accurate from both metric and visual points of view. This stresses once again the relevance of proper digital metric documentation of cultural heritage and museum buildings.

The digitisation process of a large building is a challenging and time-consuming process, this effort must therefore be used for multiple purposes. In a museum, great attention is obviously paid to the collections, but the experiences presented show the close connection between the historical building and its content. In this direction, a digital survey of the entire Pitti Palace is currently underway, which will lead to a global model of this important architectural heritage, useful both for deeper knowledge and for improving its management.

\section{Acknowledgements}

We thank Dr Eike Schimdt, director of Le Gallerie degli Uffizi. We also thank the curators of the exhibition "Weaving a Biography. The tapestries in honour of Cosimo I", Dr Alessandra Griffo and Dr Lucia Meoni, together with Dr Cinzia Nenci, whose enquires led to this research. We also finally thank arch. Gabriele Tori for his contribution to the making of the video and the virtual reality project.

\section{References}

Airstar. (2021). Airstar lighting balloons: World leader, inventor and manufacturer. Retrieved November 27, 2020, from http://www.airstar-light.com/en/ 
Angheluță, L.M. \& Rădvan, R., (2020). 3D Digitization of translucid materials in Cultural Heritage objects: a comparative study between laser scanning and photogrammetry. Romanian Journal of Physics 65(7-8 (906)):1. Retrieved November 27, 2020, from http://www.nipne.ro/rjp/2020_65_7-8/RomJPhys.65.906.pdf

Bandini, F., Felici, A., Lanfranchi, M. \& Mariotti, P. (2009). II restauro dei soffitti delle tre Sale dei Pianeti in Pitti Palace a Firenze. OPD Restauro, (21), 145-160. Retrieved November 27, 2020, from http://www.jstor.org/stable/24395673 (27.11.2020)

Banfi, F. (2020). HBIM, 3D drawing and virtual reality for archaeological sites and ancient ruins. Virtual Archaeology Review, 11(23), 16-33. https://doi.org/10.4995/var.2020.12416

Bekele, M. K., Pierdicca, R., Frontoni, E., Malinverni, E. S. \& Gain, J. (2018). A survey of augmented, virtual, and mixed reality for cultural heritage. Journal on Computing and Cultural Heritage, 11(2), 1-36. https://doi.org/10.1145/3145534

Bertelli, S. (2002). Palazzo Pitti dai Medici ai Savoia.. In Bellinazzi, A. (Ed.) La Corte di Toscana dai Medici ai Lorena. Atti. Firenze 1997. Pubblicazioni degli Archivi di Stato: Saggi, 71, 11-109. Roma, Italy: Ministero dei Beni Culturali

D.M. 113 (2018). Adozione dei livelli minimi uniformi di qualita' per i musei e i luoghi della cultura di appartenenza pubblica e attivazione del Sistema museale nazionale. Ministerial Decree. Gazzetta Ufficiale della Repubblica Italiana Serie Generale 78, 04-04-2018. Retrieved November 27, 2020, from https://www.gazzettaufficiale.it/eli/id/2018/04/04/18A02353/sg

Eliseu S., Lopes M. M., Ribeiro J.P. \& Oliveira F. (2020). Learning and Creativity Through a Curatorial Practice Using Virtual Reality. In Stephanidis C. et al. (Eds) HCl International 2020 - Late Breaking Papers: Cognition, Learning and Games. HCII 2020. Lecture Notes in Computer Science, vol 12425. Cham, Germany: Springer. https://doi.org/10.1007/978-3-030-60128-7_28

Fazio, L. \& Lo Brutto, M. (2020). 3D survey for the archaeological study and virtual reconstruction of the "Sanctuary of Isis" in the ancient Lilybaeum (Italy). Virtual Archaeology Review, 11(22), 1-14. https://doi.org/10.4995/var.2020.11928

LaboratorioGeCO. (2020). Weaving a Biography: $17^{\text {th }}$ century tapestries in honour of Cosimo I. [Video file]. Retrieved November 27, 2020, from https://youtu.be/3406gZFWMX8

Gifreu-Castells, A. (2019). Approach to the Curatorship of Virtual Reality Exhibitions. In Buckley B. \& Conomos J. (Eds.) A Companion to Curation. Hoboken, NJ: Wiley. https://doi.org/10.1002/9781119206880.ch19

Greco, C. (2019). Keynote: The biography of objects. International Archives of the Photogrammetry, Remote Sensing and Spatial Information Sciences. XLII-2/W11, 5-10. https://doi.org/10.5194/isprs-archives-XLII-2-W11-5-2019

Greco, C., Rossi, C. \& Della Torre,S. (2020). Digitalizzazione e patrimonio culturale tra crisi e opportunità: l'esperienza del Museo Egizio di Torino / Digitalization and Cultural Heritage between Crisis and Opportunities: the Experience of the Egyptian Museum in Turin. II capitale culturale. Studies on the Value of Cultural Heritage, Suppl.11, 197212. https://doi.org/10.13138/2039-2362/2532

Gregory, I. \& Murrieta-Flores, P. (2016). Geographical information systems as a tool for exploring the spatial humanities. In C. Crompton, R. Lane, \& R. Siemens (Eds.), Doing Digital Humanities: Practice, Training, Research. Oxford, United Kingdom: Routledge

Griffo, A., \& Meoni, L. (2019). Una biografia tessuta: gli arazzi seicenteschi in onore di Cosimo I. Livorno, Italy: Sillabe

Huaman E.M.R., Aceituno R.G.A. \& Sharhorodska O. (2019). Application of Virtual Reality and Gamification in the Teaching of Art History. In Zaphiris P., loannou A. (Eds) Learning and Collaboration Technologies. Ubiquitous and Virtual Environments for Learning and Collaboration. HCII 2019. Lecture Notes in Computer Science, vol 11591. Cham, Germany: Springer. https://doi.org/10.1007/978-3-030-21817-1_17

Lazzeretti, L. \& Sartori, A. (2016). Digitisation of Cultural Heritage and Business Model Innovation: The Case of the Uffizi Gallery in Florence. II capitale culturale. Studies on the Value of Cultural Heritage, 14. http://doi.org/10.13138/2039-2362/1436

Luhmann, T., Chizhova, M., Gorkovchuk, D., Hastedt, H., Chachava, N. \& Lekveishvili, N. (2019). Combination of Terrestrial Laserscanning, Uav and Close-Range Photogrammetry for 3d Reconstruction of Complex Churches in Georgia. International Archives of the Photogrammetry, Remote Sensing and Spatial Information Sciences, XLII2/W11, 753-761. https://doi.org/10.5194/isprs-archives-XLII-2-W11-753-2019

Mandelli, A., Perfetti, L., Fiorillo, F., Fassi, F., Rossi, C. \& Greco, C.. (2019). The digitalization of ancient Egyptian coffins: a discussion over different techniques for recording fine details. International Archives of the Photogrammetry, Remote Sensing and Spatial Information Sciences. XLII-2/W15. 743-750. https://doi.org/10.5194/isprs-archivesXLII-2-W15-743-2019

Münster, S., Friedrichs, K. \& Hegel, W. (2018). 3D Reconstruction Techniques as a Cultural Shift in Art History?. International Journal for Digital Art History, 3. https://doi.org/10.11588/dah.2018.3.32473

Münster, S. \& Terras, M. (2019). The visual side of digital humanities: A survey on topics, researchers, and epistemic 
cultures. Digital Scholarship in the Humanities, 35(22), 366-389. https://doi.org/10.1093/llc/fqz022

NEMECH (2020). MuseiEmotivi e motivi post_Covid-19. Ascoltare i partecipanti. Retrieved November 27, 2020, from http://nemech.unifi.it/MuseiEmotivi_reports/MUSEIEMOTIVI_e_motivi_post_Covid_19.pdf

NEMO (2020). Survey on the impact of the COVID-19 situation on museums in Europe. Retrieved November 27, 2020, from https://www.ne-mo.org/fileadmin/Dateien/public/NEMO_documents/NEMO_COVID19_Report_12.05.2020.pdf

Open Data Directive (2019). Directive (EU) 2019/1024 of the European Parliament and of the Council of 20 June 2019 on open data and the re-use of public sector information. Official Journal of the European Union, English edition $L$ 172, 26 June 2019. Retrieved November 27, 2020, from https://eur-lex.europa.eu/eli/dir/2019/1024/oj

Tucci, G., Betti, M., Conti, A., Corongiu, M., Fiorini, L., Matta, C., Kovačević, C., Borri, C. \& Hollberg, C. (2019a). BIM for Museums: An Integrated Approach from the Building to the Collections. International Archives of the Photogrammetry, Remote Sensing and Spatial Information Sciences, 4211, 1089-1096. https://doi.org/10.5194/ISPRS-ARCHIVES-XLII-2-W11-1089-2019

Tucci, G., Bonora, V., Conti, A. \& Fiorini, L. (2017). High-quality 3D models and their use in a cultural heritage conservation project. International Archives of the Photogrammetry, Remote Sensing and Spatial Information Sciences, XLII-2/W5, 687-693. https://doi.org/10.5194/isprs-archives-XLII-2-W5-687-2017

Tucci, G., Conti, A., Fiorini, L., Corongiu, M., Valdambrini, N. \& Matta, C. (2019b). M-BIM: a new tool for the Galleria dell'Accademia di Firenze. Virtual Archaeology Review, 10(21), 40-55. https://doi.org/10.4995/var.2019.11943

Unity Technologies (2021). Unity Technologies. Unity Real-Time Development Platform | 3D, 2D VR \& AR Engine. Retrieved November 27, 2020, from https://unity.com/ 